GRASAS Y ACEITES 69 (4)

October-December 2018, e279

ISSN-L: 0017-3495

https://doi.org/10.3989/gya.0101181

\title{
Effect of ohmic cooking followed by an infrared cooking method on lipid oxidation and formation of polycylic aromatic hydrocarbons (PAH) of beef muscle
}

\author{
A. Uzun Özcan ${ }^{\mathrm{a}, \bigotimes}$ M. Maskan ${ }^{\mathrm{b}}$, M. Bedir ${ }^{\mathrm{c}}$ and H. Bozkurt ${ }^{\mathrm{b}}$ \\ ${ }^{a}$ Kilis 7 Aralık University, Engineering and Architecture Faculty, Food Engineering Department \\ ${ }^{\mathrm{b}}$ University of Gaziantep, Engineering Faculty, Food Engineering Department \\ ${ }^{c}$ University of Gaziantep, Engineering Faculty, Physics Engineering Department \\ Corresponding author: aniluzunozcan@kilis.edu.tr
}

Submitted: 02 January 2018; Accepted: 08 June 2018

\begin{abstract}
SUMMARY: In this study, the effects of ohmic cooking alone and a consecutive application of ohmic and infrared cooking on lipid oxidation and polycyclic aromatic hydrocarbon $(\mathrm{PAH})$ formation in beef was investigated. In consecutive cooking, samples were first cooked ohmically at 40, 55 and 70 Volt for 7 minutes, then infrared cooking was applied to each side of ohmically cooked beef samples at 3 different temperatures $\left(325,375\right.$ and $\left.425^{\circ} \mathrm{F}\right)$ for 3 minutes. The thiobarbituric acid reactive substance (TBARS) levels of the samples were found between 0.31 and $1.74 \mathrm{mg} \mathrm{MDA} / \mathrm{kg}$. Increasing the voltage level in ohmic cooking caused a significant $(\mathrm{P}<0.05)$ increase in the TBARS value. In the consecutive application of ohmic and infrared cooking, infrared cooking temperature caused a significant $(\mathrm{P}<0.05)$ increase in the TBARS value at the same voltage levels. In this study, working with 40 and 55 Volts for ohmic cooking alone and $40 \mathrm{~V}-325^{\circ} \mathrm{F}, 40 \mathrm{~V}-375^{\circ} \mathrm{F}$ settings for ohmic-infrared cooking gave a generally acceptable threshold level for TBARS value $(1 \mathrm{mg} / \mathrm{kg})$. About 12 polycyclic aromatic hydrocarbons (PAHs) were detected in the cooked beef by ultra-performance liquid chromatography fluorescence detector (UPLC-FD). Benzo(a)pyrene (BaP), which is the most common PAH, was detected at between 1.2514 and $1.4392 \mu \mathrm{g} / \mathrm{kg}$ and 4 PAH (sum of Benzo(a)pyrene, Chrysene, Benz(a)anthracene, Benz(b)fluoranthene) levels were detected at between 1.2514- $3.7844 \mu \mathrm{g} / \mathrm{kg}$. The results of PAHs were reasonably below the European Commission regulation limits, which are very important and indicate that the cooking processes applied in this study are safe.
\end{abstract}

KEYWORDS: Beef cooking; Infrared; Lipid oxidation; Ohmic; PAH

RESUMEN: Efecto de la cocción óhmica seguida de un método de cocción infrarrojo sobre la oxidación de lípidos y la formación de hidrocarburos aromáticos policíclicos (HAP) de músculo de vaca. En este estudio se investigaron los efectos de la cocción óhmica sola y la aplicación consecutiva de cocción óhmica e infrarroja sobre la oxidación de lípidos y la formación de hidrocarburos aromáticos policíclicos (HAP) en carne de res. En cocción consecutiva, las muestras se cocieron primero óhmicamente a 40, 55 y 70 voltios durante 7 minutos, seguidamente se aplicó una cocción infrarroja a cada lado de las muestras de carne de res cocidas óhmicamente a 3 temperaturas diferentes $\left(325,375\right.$ y $\left.425^{\circ} \mathrm{F}\right)$ durante 3 minutos. Los niveles de las sustancias reactivas al ácido tiobarbitúrico (TBARS) de las muestras se encontraron entre 0,31 y 1,74 mg de MDA/kg. Aumentar el nivel de voltaje en la cocción óhmica ocasiona un aumento significativo $(\mathrm{P}<0.05)$ en el valor de TBARS. En la aplicación consecutiva de cocción óhmica e infrarroja, la temperatura de cocción infrarroja causó un aumento significativo $(\mathrm{P}<0.05)$ en el valor TBARS con los mismos valores de voltaje. En este estudio, trabajando con valores de 40 y 55 voltios para la cocción óhmica sola y $40 \mathrm{~V}-325^{\circ} \mathrm{F}$, los ajustes de $40 \mathrm{~V}-375^{\circ} \mathrm{F}$ para cocción infrarroja óhmica dieron un nivel umbral generalmente aceptable para el valor de TBARS $(1 \mathrm{mg} / \mathrm{kg})$. Se detectaron aproximadamente 12 hidrocarburos aromáticos policíclicos (HAP) en carne de res cocida mediante el uso de un detector de fluorescencia de cromatografía líquida de alta resolución (UPLC-FD). El benzo (a) pireno (BaP), que es la HAP más común, se detectó entre 1,2514 y 1,4392 $\mu \mathrm{g} / \mathrm{kg}$ y los niveles de PAH4 (suma de Benzo (a) pireno, criseo, Benz (a) antraceno, Benz (b) fluoranteno) detectado entre $1.2514-3.7844 \mu \mathrm{g} / \mathrm{kg}$. Los resultados de los HAP estuvieron razonablemente por debajo de los límites de la regulación de la Comisión Europea, que son muy importantes, lo que significa que los procesos de cocción aplicados en este estudio son seguros.

PALABRAS CLAVE: Carne de vaca cocinada; HAP; Infrarrojo; Óhmica; Oxidación de lípidos

ORCID ID: Uzun Özcan A https://orcid.org/0000-0003-4039-9389, Maskan M https://orcid.org/0000-0001-6313897X, Bedir M https://orcid.org/0000-0001-7772-3635, Bozkurt H https://orcid.org/0000-0003-4676-6354

Citation/Cómo citar este artículo: Uzun Özcan A, Maskan M, Bedir M, Bozkurt H. 2018. Effect of ohmic cooking followed by an infrared cooking method on lipid oxidation and formation of polycylic aromatic hydrocarbons (PAH) of beef muscle. Grasas Aceites $\mathbf{6 9}$ (4), e279. https://doi.org/10.3989/gya.0101181

Copyright: (C2018 CSIC. This is an open-access article distributed under the terms of the Creative Commons Attribution 4.0 International (CC BY 4.0) License. 


\section{INTRODUCTION}

Meat usually has to be cooked prior to consumption. Cooking causes several positive effects on meat such as taste and flavor enhancement, reduction in microbial load, increased shelf life and improved digestibility; but it also produces some negative effects, such as lipid oxidation and polycyclic aromatic hydrocarbon (PAH) formation (Broncano et al., 2009).

Lipid oxidation is one of the major causes of deterioration in meat quality. The products of fatty acid oxidation such as aldehydes, alkenes, ketones and alcohols cause off-flavors and off-odors in meat which are usually described as rancid. Lipid oxidation in muscle systems is initiated at the membrane level in the phospholipid fractions as a free-radical autocatalytic chain mechanism in which pro-oxidants contact with unsaturated fatty acids resulting in the generation of free radicals and multiplication of the oxidative chain (Campo et al., 2006). The oxidation of membrane lipids, one of the primary events in oxidative cellular damage, can be assessed by measuring plasma malondialdehyde (MDA), a breakdown product of lipid peroxides (Autrup et al., 1999). Malonaldehyde, which is a degradation product of lipid oxidation, has been highlighted as a carcinogenic factor in food materials (Cheng, 2016).

Another important point to be evaluated in cooked meat to determine whether the cooking method is safe or not is the formation of polycyclic aromatic hydrocarbons (PAH). PAH is formed as a result of the incomplete combustion of organic products. Meat can be contaminated with PAH mainly during the cooking process. Therefore, it is important to evaluate the formation of PAH in beef due to different cooking methods and suggest safe cooking methods (Park et al., 2017). Numerous techniques have been employed for the cooking of meat but variations in cooking time, temperature, meat palatability and meat heterogeneous structures prevent the universal use of any single technique. However, an economical, less treated, safe and simple alternative cooking method for consumers is required (Vasanthi et al., 2007). Nowadays, the quality and safety of meat has received considerable attention in order to satisfy consumer demands.

The ohmic cooking method is one such alternative method. The advantages of ohmic cooking over conventional heating include shorter processing times, higher yields, and less power consumption while still maintaining the nutritional value of meat products (Yildı-Turp et al., 2013). Ohmic cooking is an emerging thermal processing technology and the process can be described as an electrical current passing directly through a food and the resistance against the electric current by the food leads to the generation of heat within the product (Lyng et al., 2009). Ohmic cooking generates heat by direct energy application in a volumetric fashion, which reduces the long cooking times associated with conventional methods (Lyng et al., 2010). Ohmic cooking potentially offers safety for faster and instant cooking of meat products. However, meat samples commonly have heterogeneous structures because of their fat content which affects the uniform distribution of heat (Yildiz-Turp et al., 2013). It is anticipated that the ohmic cooking method should not be sufficient to be carried out alone. It should be combined with another alternative method that is economical, easy to apply and does not have negative effects on the safety and quality of the meat. For this reason, applying infrared cooking after ohmic cooking is considered to be effective in terms of practical usage, safer products, shorter processing time, homogeneous structure, a desired crust color formation and a crust layer on the outer surface of beef meat. In the literature, there is not much information about the details of the combination of these two methods for cooking meat. Therefore, this study aimes to investigate the effect of ohmic cooking alone and the consecutive application of ohmicinfrared cooking methods on undesired results of cooking meat, which are lipid oxidation and polycyclic aromatic hydrocarbon (PAH) generation.

\section{MATERIALS AND METHODS}

\subsection{Sample and reagents}

Beef (Longissumus dorsi) loin from a single threeyear-old cow was obtained from a local supermarket in Gaziantep, Turkey and used as the sample. Longissumus dorsi is the muscle that runs along the top of the spine from hip to shoulder. The meat was frozen at $-70{ }^{\circ} \mathrm{C}$ until use for cooking. The required meat samples were removed from the freezer and allowed to thaw for one day at $4{ }^{\circ} \mathrm{C}$.

Standard PAH, which is the EPA Method 8310 PAH mixture, and a Pinnacle II PAH $4 \mu \mathrm{m}$ column (LC columns, $50 \times 3.2 \mathrm{~mm}$, USA) were purchased from RESTEK. All chemicals required for calibrations and analyses were UPLC grade. Thiobarbituric acid (TBA), tetramethoxypropane, trichloroaceticacid (TCA) and the rest of the reagents and solvents used in this study were purchased from Sigma-Aldrich.

\subsection{Preparation of standard solutions}

A standard calibration was prepared using 1,1,3,3-tetramethoxypropane (TMP). First of all, a $166 \mu$ TMP solution was completed to 1 liter with pure water to prepare the stock solution. Then $0.1 \mathrm{ml}, 0.2 \mathrm{ml}, 0.3 \mathrm{ml}, 0.4 \mathrm{ml}, 0.5 \mathrm{ml}, 0.7 \mathrm{ml}$ and $1.0 \mathrm{ml}$ were taken from the stock solution and each of them was completed to $10 \mathrm{ml}$ with pure water. After that, a $0.5 \mathrm{ml}$ solution was taken into tubes 
from each dilution and homogenized with $5 \mathrm{ml} 10 \%$ TCA. Then the homogenized solution was centrifuged for 20 minutes. About $2 \mathrm{ml}$ of supernatant were taken and mixed with $2 \mathrm{ml}$ of $1 \%$ thiobarbituricacid (TBA). The mixture was placed in a $95^{\circ} \mathrm{C}$ water bath and kept for 30 minutes. At the end of this step, shock cooling was applied to the standard samples. Finally, the absorbance was read at $532 \mathrm{~nm}$ against a blank in a spectrophotometer so that a standard curve was obtained.

Stock solutions of the PAH standard (EPA Method 8310 PAH mixture, Restek) were prepared by dissolving it in ultrapure water (EMD Millipore, Merck KGaA, Germany). First of all, $50 \mu \mathrm{PAH}$ standard mixture were completed to $50 \mathrm{ml}$ with ultrapure water in order to prepare a stock solution of $500 \mathrm{ppb}$ concentration. Then, one by one $6 \mathrm{ml}$, $4 \mathrm{ml}, 2 \mathrm{ml}, 1 \mathrm{ml}$ and $0.5 \mathrm{ml}$ were taken from the stock solution and each of them was completed to $10 \mathrm{ml}$ with pure water. In this way, $300 \mathrm{ppb}, 200 \mathrm{ppb}$, $100 \mathrm{ppb}, 50 \mathrm{ppb}$ and $25 \mathrm{ppb}$ concentrations of stock solution were prepared. The $300 \mathrm{ppb}$ stock solution of the PAH chromatogram is shown in Figure 1.

\subsection{Ohmic cooking procedure and electrode designation}

For the designation of the ohmic cooker, a $5 \mathrm{kw}$ conductor, a 220 Volt input - 24 Volt output AC power supply, a limit switch, a $10 \mathrm{~A}$ fuse, a voltmeter and an ampermeter were used. The ohmic cooking design is shown in Figure 2. A cylindirical test cell with the dimensions of $5 \mathrm{~cm}$ length and $3.5 \mathrm{~cm}$ diameter was designed with open edges to hold the sample. Then, electrodes with $3.5 \mathrm{~cm}$ diameter that contact and cover the meat's surface completely were needed. Stainless steel electrodes (430 type) were tested and cooking was very successful. For this system, the meat was cut by a $5 \mathrm{~cm}$ diameter sharp cutter and then placed into the test cell. Next, 430 type stainless steel electrodes were placed into the open gaps at the edges of the test cell to completely cover and be in contact with the surface of the meat sample. The homogeneous and uniform cooking of the meat was achieved. 40, 55 and 70 Volt levels were used and the application time was adjusted to 7 minutes for ohmic cooking. Two replicates were performed for each level.

\subsection{Infrared cooking procedure}

Infrared cooking was performed in a Frigidaire Professional Stainless Programmable 6 Slice Infrared Convection Oven (Frigidaire, FPCO06D7MS 120V$60 \mathrm{~Hz} 1500$ Toaster Oven, US). In infrared cooking, three different temperature settings were used: $162.77^{\circ} \mathrm{C}\left(325^{\circ} \mathrm{F}\right), 190.55^{\circ} \mathrm{C}\left(375^{\circ} \mathrm{F}\right)$ and $218.33^{\circ} \mathrm{C}$ $\left(425^{\circ} \mathrm{F}\right)$, as the oven temperature and the temperature in the center of the meat sample was $72{ }^{\circ} \mathrm{C}$. For ohmic cooking followed by infrared cooking, the time of infrared cooking was 3 minutes for each side of the meat sample. Two replicates made for each treatment at every level.

\subsection{Experimental set-up design}

The experimental set-up design is shown in Figure 3. A flow diagram of the experimental design is shown in Figure 4.

\subsection{Determination of TBARS (Thiobarbituric acid reactive substances)}

The determination of TBARS is the most common method for the measurement of lipid oxidation in meat and consists of the spectrophotometric

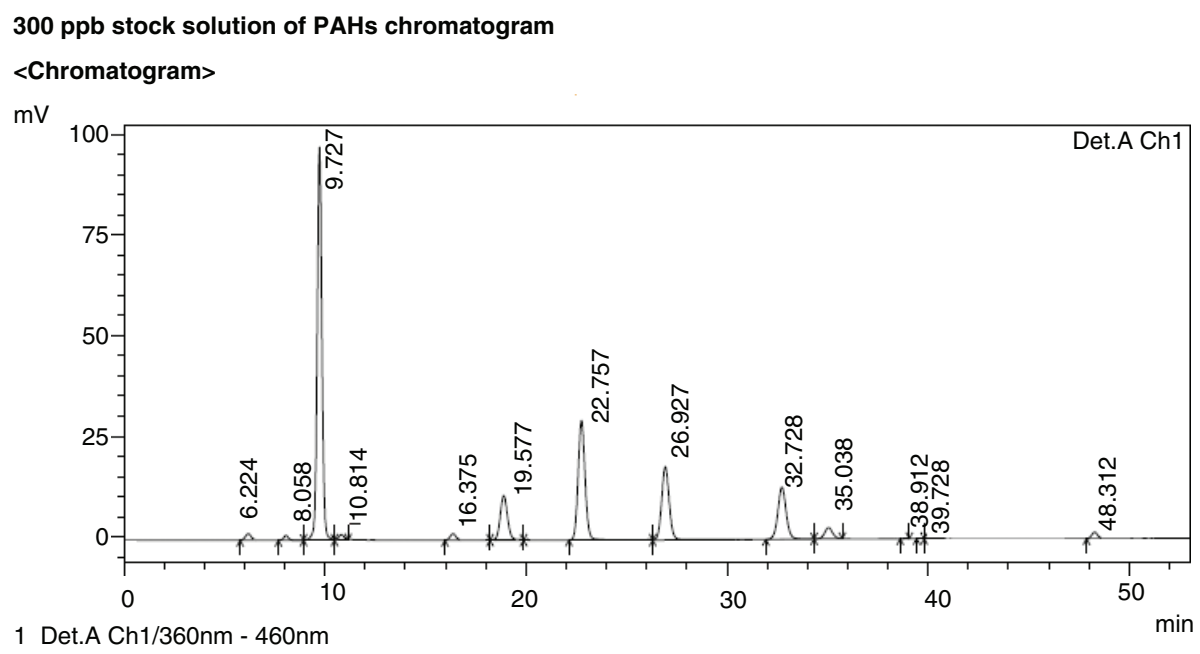

FIGURE 1. $300 \mathrm{ppb}$ stock solution of PAHs chromatogram. 


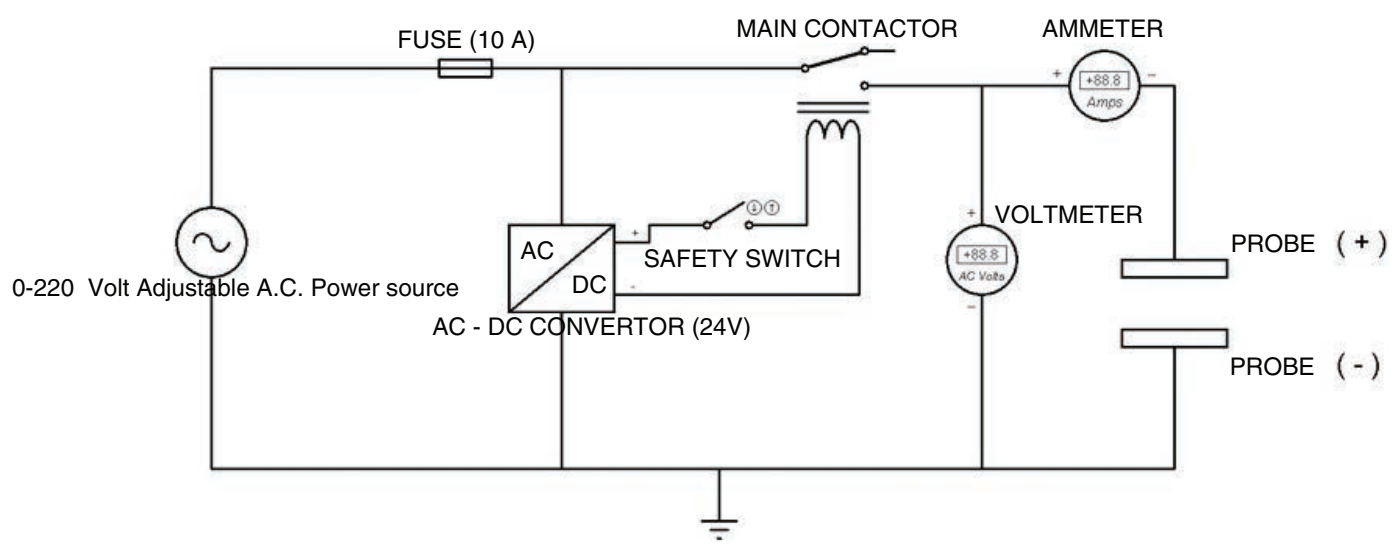

FIgURE 2. Ohmic cooking design.

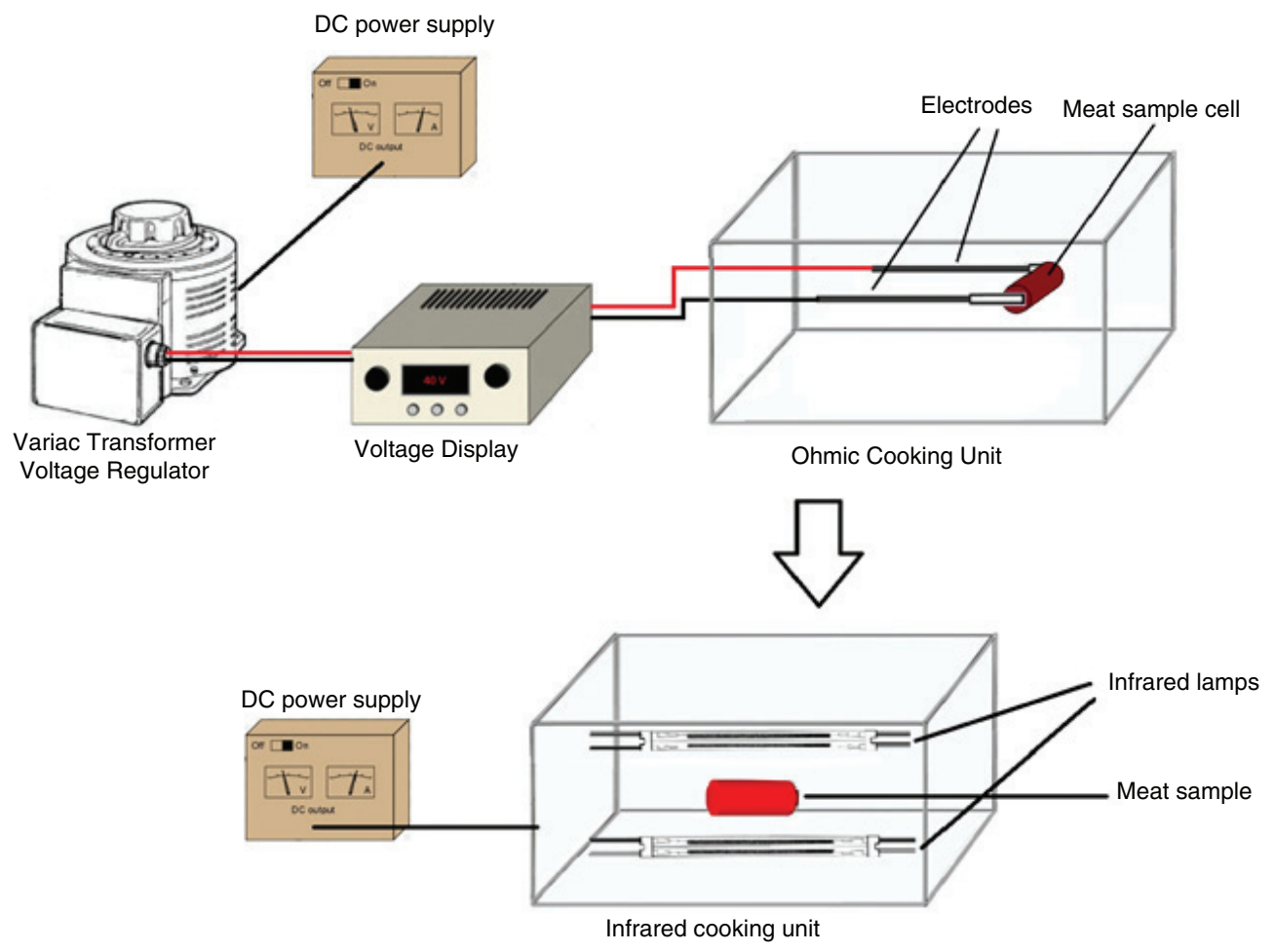

Figure 3. Experimental Set-Up Design.

determination of MDA formation as an index of oxidative status. About $1 \mathrm{~g}$ of the meat sample was taken and homogenized with $5 \mathrm{ml}$ of $10 \%$ TCA. This homogenized solution was centrifuged for 20 minutes. About $2 \mathrm{ml}$ supernatant were taken and mixed with $2 \mathrm{ml}$ of $1 \%$ TBA. The mixture was placed in a water bath at $95{ }^{\circ} \mathrm{C}$ and kept for 30 minutes. At the end of this step, shock cooling was applied to standard samples. Finally, absorbance values were read at $532 \mathrm{~nm}$ against a blank and TBARS values of the sample were determined with the calibration curve equation. The analyses were performed on duplicate samples. The result of the calibration curve equation was found to be: $\mathrm{y}=0.0391 \mathrm{x}$, where $\mathrm{y}$ is the absorbance and $\mathrm{x}$ is the $\mathrm{mg} \mathrm{MDA} / \mathrm{kg}$.

\subsection{Sample extraction and clean-up}

The extraction and clean-up procedures were carried out according to the method described by Chung et al., (2011) and Kendirci et al., (2014). A $30 \mathrm{~g}$ sample was placed in a $500 \mathrm{ml}$ round flask, and $100 \mathrm{ml} \mathrm{KOH} \mathrm{(2} \mathrm{M,} \mathrm{prepared} \mathrm{by} \mathrm{using} \mathrm{a} \mathrm{methanol}$ in water [9:1]) solution and $100 \mathrm{ml}$ of hexane were added. The flask was held in a water bath at $80 \pm 2{ }^{\circ} \mathrm{C}$ under reflux for 2 hours. Then, it was cooled to 


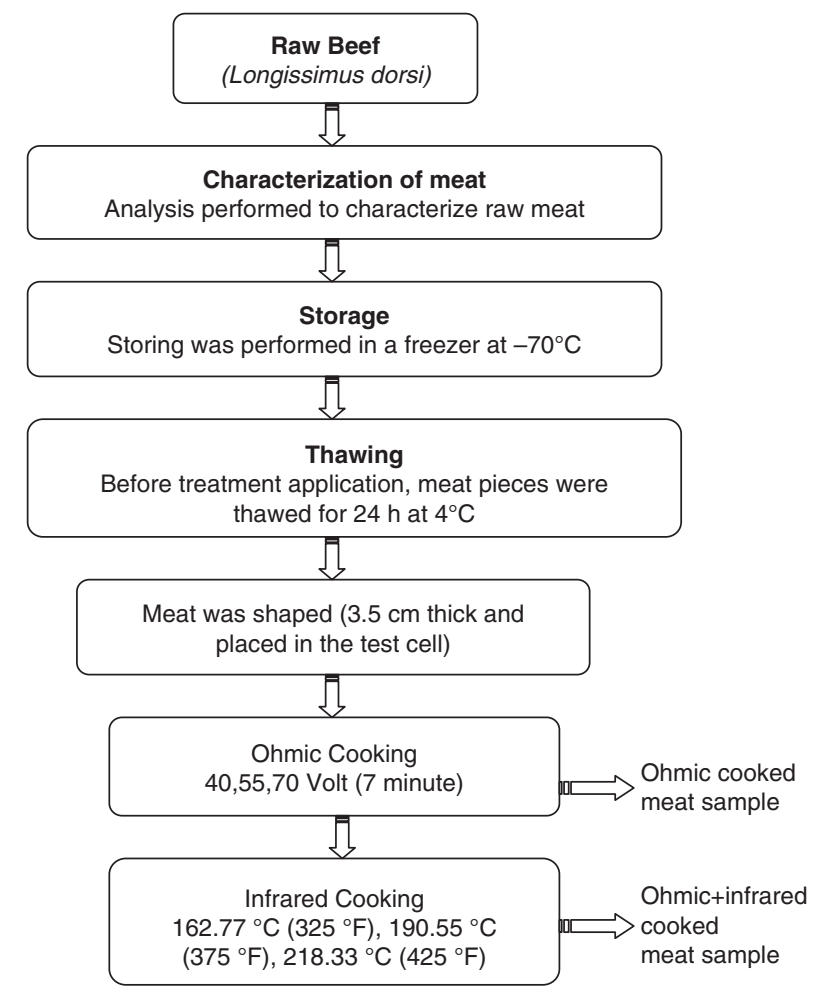

FIgURE 4. Flow diagram of cooking system.

approximately $40^{\circ} \mathrm{C}$ by adding $100 \mathrm{ml}$ of cold water and allowed to stand overnight in the dark. The hexane phase was transferred into a $250 \mathrm{ml}$ Erlenmeyer flask and concentrated to $2 \mathrm{ml}$ at $50 \pm 2{ }^{\circ} \mathrm{C}$ using a vacuum oven. The concentrate was purified by moving it through a Sep-Pak florisil cartridge (Vac C18 6 cc, Waters Corporation, USA), which had been pre-conditioned with $10 \mathrm{ml}$ of dichloromethane and $20 \mathrm{ml}$ hexane. Elution solvents involving $10 \mathrm{ml}$ hexane and $8 \mathrm{ml}$ hexane:dichloromethane (3:1) were moved through the cartridge. All the eluates were collected, dissolved in $1 \mathrm{ml}$ of acetonitrile, filtered through a $0.45 \mu \mathrm{m}$ membrane filter (Minisart RC 25 , Germany) and collected into $2 \mathrm{ml}$ amber vials.

\subsection{PAH determination}

The PAH analysis was carried out with a UPLC device equipped with a fluorescence detector. A Pinnacle-II PAH $4 \mu \mathrm{m}$ column (Restek LC columns, $50 \times 3.2 \mathrm{~mm}$, USA) was used. The gradient solvent system was started with $50 \%$ acetonitrile in water (v/v) and linearly increased to $100 \%$ acetonitrile in 30 min at a flowrate of $0.5 \mathrm{ml} / \mathrm{min}$. The excitation and emission wavelengths were $360 / 460 \mathrm{~nm}$. The external calibration curves of the PAHs were prepared by injecting $10 \mu \mathrm{l}$ of working solutions of the standards to HPLC. For the quantification of the PAHs, a 10 $\mu l$ sample extract was injected into the HPLC. The analyses were performed on duplicate samples. The retention times (Rt) and limit of detections (LODs) of PAHs are shown in Table 3.

\subsection{Statistical analyses}

An ANOVA was performed for TBARS and PAH levels as a function of voltage value for ohmic cooking alone and cooking temperature for the combined ohmic-infrared cooking. SPSS version 21.0 was used to evaluate significant differences $(\mathrm{P}<0.05)$ among the samples. For the identification of the homogeneous groups of cooking methods' variables, Duncan's multiple range test was applied. Trends were considered as significant when the means of the compared parameters differed at a $\mathrm{P}<0.05$ significance level.

\section{RESULTS AND DISCUSSION}

\subsection{Lipid oxidation}

Lipid oxidation values in meat, after ohmic cooking alone and ohmic cooking followed by infrared cooking are expressed as $\mathrm{mg} \mathrm{MDA} / \mathrm{kg}$ muscle and presented in Tables 1 and 2. In the ohmic cooking process alone, increasing the voltage value increased the TBARS value significantly $(\mathrm{P}<0.05)$. In ohmic processing, the increase in temperature could be due to the agitation of molecules due to the movement of charges within the material by the flow of electric current through a conductor (Ramaswamy et al., 2014). Min et al., (2006) investigated the effect of different ohmic power intensities $(0,10,20,30$, $40,50 \mathrm{~V})$ on the TBARS levels of hamburger patties. They argued that thermal processing can promote lipid oxidation by disrupting cell membranes and releasing pro-oxidants. They concluded that increasing ohmic power intensity tended to increase the TBARS levels. Also, higher ohmic power intensity at $50 \mathrm{~V}$ increased the lipid oxidation in all patties. Piette et al., (2004), studied bologna samples where they applied ohmic cooking and reached a fixed target temperature $\left(70{ }^{\circ} \mathrm{C}\right)$, with 3 different voltage densities $\left(2.9,3.5\right.$, and $\left.4.7 \mathrm{~V} \mathrm{~cm}^{-1}\right)$.

TABLE 1. Lipid oxidation value; TBARS (mg MDA/kg) values for ohmic cooked beef.

\begin{tabular}{lc}
\hline Ohmic Cooking (Volt) & TBARS (mg MDA/kg) \\
\hline Raw meat & $0.31 \pm 0.03^{\mathrm{a}}$ \\
40 & $0.59 \pm 0.03^{\mathrm{b}}$ \\
55 & $0.87 \pm 0.07^{\mathrm{c}}$ \\
70 & $1.30 \pm 0.03^{\mathrm{d}}$ \\
\hline
\end{tabular}

* Results are reported as mean value \pm standard deviation of four data. Abbreviations: Volt; voltage value, TBARS; thiobarbituric acid reactive substances, $\mathrm{mg}$ MDA $/ \mathrm{kg}$; miligram malondialdehyde/kilogram. Different small letters indicate that means in the same column are significantly different $(\mathrm{P}<0.05)$. 
They observed that higher ohmic voltage values caused faster heating rates. Higher heating rates facilitate free radical production, greatly accelerating lipid oxidation.

During the consecutive application of ohmic and infrared cooking, at the same voltage level, increasing infrared temperature caused a significant $(\mathrm{P}<0.05)$ increase in TBARS value (Table 2$)$. Infrared is a form of electromagnetic energy that can cause heating on the surface of objects when absorbed (Huang and Sites, 2012). As shown in Table 2, higher TBARS values were obtained from the consecutive application of ohmic-infrared cooking compared to the ohmic cooking alone process. This could be due to the exposure of the meat's surface to higher temperatures and to the cooperative effects of thermal damage to the membrane phospholipids and heat denaturation of proteins during exposure to ohmic- infrared temperatures (Zell et al., 2010a).

In this study, TBARS levels were found at 0.31 mg MDA/kg for raw beef and 0.59-1.74 mg MDA/ $\mathrm{kg}$ for cooked products. In this respect, Broncano et al., (2009) emphasized that there are many studies available which demonstrate how different kinds of cooked meat have higher levels of TBARS in comparison to raw meat. Broncano et al., (2009) studied the influence of different cooking methods [grilled (GR), fried (FP), microwaved (MW) and roasted (RO)] on lipid oxidation, and found TBARS value of $0.26 \mathrm{mg} \mathrm{MDA} / \mathrm{kg}$ for raw, $0.86 \mathrm{mg} \mathrm{MDA} / \mathrm{kg}$ for grilled, $1.19 \mathrm{mg} \mathrm{MDA} / \mathrm{kg}$ for fried, $1.03 \mathrm{mg} \mathrm{MDA} / \mathrm{kg}$

TABLE 2. Lipid oxidation value; TBARS (mg MDA/kg) values for ohmic+infrared cooked beef.

\begin{tabular}{lcc}
\hline $\begin{array}{l}\text { Ohmic Cooking } \\
\text { (Volt) }\end{array}$ & $\begin{array}{c}\text { Infrared } \\
\text { Cooking }\left({ }^{\circ} \mathbf{F}\right)\end{array}$ & $\begin{array}{c}\text { TBARS } \\
(\mathbf{m g} \text { MDA } / \mathbf{k g})\end{array}$ \\
\hline Raw & & $0.31 \pm 0.03^{\mathrm{a}}$ \\
& 325 & $0.74 \pm 0.14^{\mathrm{b}}$ \\
40 & 375 & $1.02 \pm 0.07^{\mathrm{c}}$ \\
& 425 & $1.33 \pm 0.07^{\mathrm{d}}$ \\
Raw & & $0.31 \pm 0.03^{\mathrm{a}}$ \\
& 325 & $1.10 \pm 0.03^{\mathrm{b}}$ \\
55 & 375 & $1.30 \pm 0.02^{\mathrm{c}}$ \\
& 425 & $1.41 \pm 0.03^{\mathrm{d}}$ \\
Raw & & $0.31 \pm 0.03^{\mathrm{a}}$ \\
& 325 & $1.56 \pm 0.03^{\mathrm{b}}$ \\
70 & 375 & $1.69 \pm 0.03^{\mathrm{c}}$ \\
& 425 & $1.74 \pm 0.00^{\mathrm{c}}$ \\
\hline
\end{tabular}

* Results are reported as mean value \pm standard deviation of four data. Abbreviations: Volt; voltage value, ${ }^{\circ} \mathrm{F}$; Fahrenheit degree, TBARS; thiobarbituric acid reactive substances, mg MDA/kg; miligram malondialdehyde/kilogram. Different small letters indicate that means are significantly different in the same column $(\mathrm{P}<0.05)$ for each voltage value of ohmic cooking. for microwave, and $1.35 \mathrm{mg} \mathrm{MDA} / \mathrm{kg}$ for the roasted Latissimus dorsi muscle of Iberian pigs. Soladoye et al., (2017) reported that the average TBARS value in raw bacon was about $0.19 \mathrm{mg} \mathrm{MD} / \mathrm{kg}$ and increased by over three-fold and four-fold after microwave and frying pan cooking (0.69 and $0.93 \mathrm{mgMD} / \mathrm{kg}$ ), respectively. The cooked beef showed an increased TBARS value compared to the raw meat, and the highest values were found when the beef was broiled at a high temperature, cooked by microwave and boiled in water in comparison to cooked in a domestic oven (Peiretti et al., 2012). Cheng, (2016) reported that pork contains more unsaturated fatty acids than beef. Therefore pork is more sensitive to lipid oxidation than beef. In our study, although TBARS results after ohmic cooking alone and ohmic-infrared cooking at 40 and 55 Volt are closer to Broncano et al., (2009)'s study, ohmicinfrared cooking at 70 Volt caused higher TBARS formation. The cooking process gains importance at this point. The ohmic-infrared cooking process caused higher TBARS formation in beef, especially at 70 Volt. Maillard et al., (1996) indicated that lipid oxidation could decrease the nutritional value by the formation of potentially toxic products during cooking and processing. Wu et al., (1991) reported that if the TBARS value is higher than $1 \mathrm{mg} / \mathrm{kg}$, off-odors are usually formed and it is considered the beginning of organoleptic perceptibility of lipid oxidation. Meat products that have a TBARS value higher than $1 \mathrm{mg} / \mathrm{kg}$ could be considered "rancid". In this case, using 40 and 55 Volt values for ohmic cooking alone and $40 \mathrm{~V}-325 \mathrm{~F}, 40 \mathrm{~V}-375 \mathrm{~F}$ for ohmicinfrared cooking is much better for maintaining the TBARS value below this generally acceptable threshold level.

TABLE 3. Retention times (Rt) and limit of detections (LODs) of 12 PAH compounds.

\begin{tabular}{lcc}
\hline PAH & RT (min.) & LOD (ppb) \\
\hline Napthalene & 6.224 & 0.2 \\
1-Methylnapthalene & 8.058 & 0.7 \\
2-Methylnapthalene & 9.727 & 0.4 \\
Acenaphthylene & 10.814 & 1.2 \\
Fluorene & 16.375 & 0.1 \\
Phenanthrene & 19.577 & 0.2 \\
Anthracene & 22.757 & 0.5 \\
Fluoranthene & 26.927 & 0.5 \\
Pyrene & 32.728 & 0.6 \\
Benz(a)anthracene & 35.038 & 0.8 \\
Chrysene & 39.728 & 1.3 \\
Benzo(a)pyrene & 48.312 & 1.2 \\
\hline
\end{tabular}

Abbreviations: PAH; polycyclic aromatic hydrocarbon, min; minutes, ppb; parts per billion. 


\subsection{Polycyclic aromatic hydrocarbons}

As can be seen in Tables 4-7, the PAH levels of cooked samples were found between 0.0233-2.9941 $\mu \mathrm{g} / \mathrm{kg}$. It can also be observed that despite the fact that 1-methylnapthalin, fluorene, anthracene and benzo(a)pyrene were detected at different levels in almost all samples treated with both methods, the other PAHs were not determined in ohmic cooking alone and detected in lower levels at consecutive application of ohmic and infrared cooking. In this sense, the lower center temperature reached and the direct energy application of ohmic cooking alone make it safer for the PAH formation compared to the consecutive application of the ohmic and infrared cooking methods.

EFSA (2008) assessed that the sum content of four PAH compounds benzo(a)pyrene, chrysene, benz(a)anthracene and benz(b)fluoranthene (PAH4) is the most suitable indicator of PAH in food. The PAH4 levels of the cooked meat samples in this study were found to be between 1.2514$3.7844 \mu \mathrm{g} / \mathrm{kg}$, as shown in Tables 5 and 7 . Kendirci et al., (2014) determined PAH4 levels between 0.62$6.21 \mu \mathrm{g} / \mathrm{kg}$ in meatball samples treated with ohmic cooking after infrared heating using different fluxes, application distances and application durations. Jira (2010) studied the PAH in representative samples of smoked meat products (raw sausages, raw ham, cooked ham, frankfurter-type sausage, liver sausages) in Germany. PAH4 levels were found for frankfurter-type sausages with a mean value of 0.6 $\mu \mathrm{g} / \mathrm{kg}$, which was the highest, in the range of $0.3 \mu \mathrm{g} /$ $\mathrm{kg}$ for raw ham and liver sausages, a $0.2 \mu \mathrm{g} / \mathrm{kg}$ mean value for raw sausages and the lowest mean value of $0.1 \mu \mathrm{g} / \mathrm{kg}$ for cooked ham. Öz and Yüzer (2016) studied the effect of type of barbecue and cooking levels on the formation of PAHs in beef steak. They found PAH4 levels which ranged between not detected and $1.30 \mathrm{ng} / \mathrm{g}$. The PAH4 results in our study were higher than these values but lower than the European Commision (EC) PAH limits. According to EC directives, the maximum limit of $4 \mathrm{PAH}$ which is permitted in smoked meat and smoked meat products is $12 \mu \mathrm{g} / \mathrm{kg}$ (EC, 2011).

The total PAH contents varied between 2.5685 and $13.6536 \mu \mathrm{g} / \mathrm{kg}$ in this study. This is relatively low in comparison with the study of DuedahlOlesen et al., (2006). They examined smoked meat samples produced in Denmark and found that the sum of PAH ranged from $24 \mu \mathrm{g} / \mathrm{kg}$ for salami to $64 \mu \mathrm{g} / \mathrm{kg}$ for bacon. Also, Elhassaneen (2004) studied the broiling of beef burgers by charcoal and detected 11 PAHs in the range of $0.31-14.95 \mathrm{mg} / \mathrm{kg}$. Panalaks (1976) indicated that barbecued meat had the greatest PAHs level at $164 \mathrm{mg} / \mathrm{kg}$ total PAHs and $30 \mathrm{mg} / \mathrm{kg}$ of benzo(a)pyrene.

$\mathrm{BaP}$ is the most common $\mathrm{PAH}$ that is present in an extensive variety of foods. Since $\mathrm{BaP}$ is one of the most powerful carcinogenic PAHs, it is very important to identify and study its level. Moreover, $\mathrm{BaP}$ is a very good indicator of other PAHs in food items; the correlation coefficient was reported as 0.87 between the total PAHs and BaP level and as 0.98 between the carcinogenic PAHs and BaP level (Kazerouni et al., 2001; Reinik et al., 2007). According to the European Commission regulation, the maximum acceptable level of $\mathrm{BaP}$ in smoked

TABLE 4. Levels of PAHs $(\mu \mathrm{g} / \mathrm{kg})$ of ohmic cooked samples.

\begin{tabular}{lccccccc}
\hline $\begin{array}{l}\text { Cooking } \\
\text { Process }\end{array}$ & Napthalene & 1-Methylnapthalene & 2-Methylnapthalene & Acenapthylene & Fluorene & Phenanthrene & Anthracene \\
\hline $40 \mathrm{~V}$ & ND & $0.7933 \pm 0.0368^{\mathrm{a}}$ & ND & ND & $0.0233 \pm 0.0326^{\mathrm{a}}$ & ND & $0.5005 \pm 0.0191^{\mathrm{a}}$ \\
$55 \mathrm{~V}$ & $\mathrm{ND}$ & $0.8311 \pm 0.0045^{\mathrm{a}}$ & $\mathrm{ND}$ & ND & $0.0061 \pm 0.0043^{\mathrm{a}}$ & ND & $0.5056 \pm 0.0111^{\mathrm{a}}$ \\
$70 \mathrm{~V}$ & $\mathrm{ND}$ & $0.9884 \pm 0.1180^{\mathrm{a}}$ & ND & ND & $0.0657 \pm 0.0871^{\mathrm{a}}$ & ND & $0.5075 \pm 0.0118^{\mathrm{a}}$ \\
\hline
\end{tabular}

* Results are reported as mean value \pm standard deviation of four data. Abbreviations: PAHs; polycyclic aromatic hydrocarbons, $\mu \mathrm{g} / \mathrm{kg}$; microgram/kilogram, V; volt, nd; not detected. Different small letters indicate that means are significantly different in the same column $(\mathrm{P}<0.05)$ for each voltage value.

TABLE 5. Levels of PAHs $(\mu \mathrm{g} / \mathrm{kg})$ of ohmic cooked samples.

\begin{tabular}{lccccccc}
\hline $\begin{array}{l}\text { Cooking } \\
\text { Process }\end{array}$ & Fluoranthene & Pyrene & $\begin{array}{c}\text { Benz (a) } \\
\text { anthracene }\end{array}$ & Chrysene & Benzo (a) pyrene & PAH4 & EPAH \\
\hline $40 \mathrm{~V}$ & ND & ND & ND & ND & $1.2514 \pm 0.3258^{\mathrm{a}}$ & $1.2514 \pm 0.0739^{\mathrm{a}}$ & $2.5685 \pm 0.0147^{\mathrm{a}}$ \\
$55 \mathrm{~V}$ & ND & ND & ND & ND & $1.2574 \pm 0.0703^{\mathrm{a}}$ & $1.2574 \pm 0.0704^{\mathrm{a}}$ & $2.6002 \pm 0.0594^{\mathrm{a}}$ \\
$70 \mathrm{~V}$ & ND & ND & ND & ND & $1.2690 \pm 0.3258^{\mathrm{a}}$ & $1.2690 \pm 0.3258^{\mathrm{a}}$ & $2.8306 \pm 0.2832^{\mathrm{a}}$ \\
\hline
\end{tabular}

* Results are reported as mean value \pm standard deviation of four data. Abbreviations: PAHs; polycyclic aromatic hydrocarbons, $\mu \mathrm{g} / \mathrm{kg}$; microgram/kilogram, V; volt, nd; not detected, PAH4; sum of $\mathrm{B}[\mathrm{a}] \mathrm{A}, \mathrm{B}[\mathrm{b}] \mathrm{F}, \mathrm{B}[\mathrm{a}] \mathrm{P}$ and $\mathrm{Chr}$, $\mathrm{PAH}$; sum of 12 PAHs detected in this study. Different small letters indicate that means are significantly different in the same column $(\mathrm{P}<0.05)$ for each voltage value. 

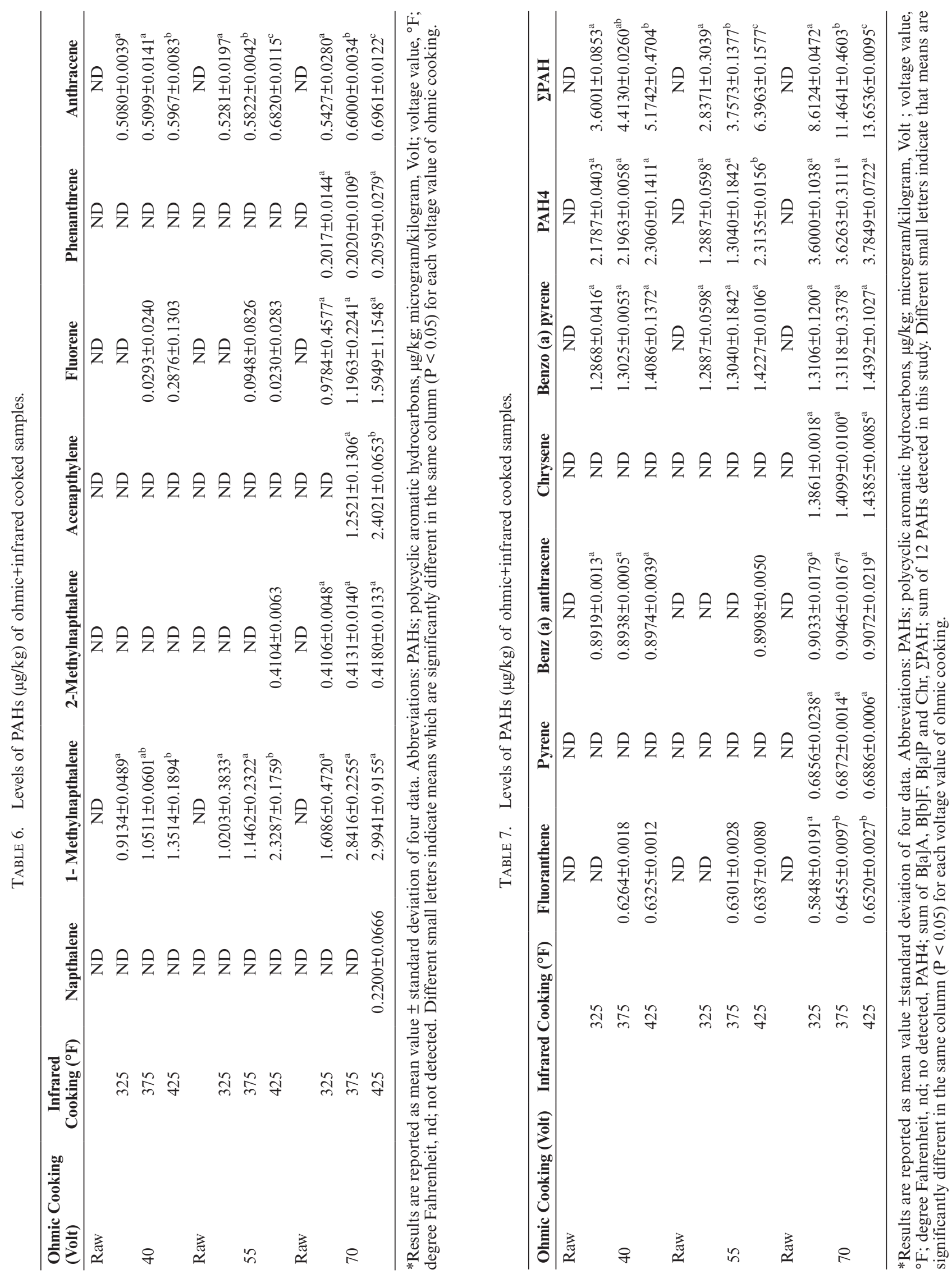
meat and smoked meat products was reported as $5 \mathrm{mg} / \mathrm{kg}$ until 31.08.2014; but from 01.09.2014 the maximum acceptable level is $2 \mathrm{mg} / \mathrm{kg}$ (EC, 2011). As can be observed from Tables 5 and 7, ohmic cooking alone and the consecutive application of ohmic and infrared cooking caused lower levels of $\mathrm{BaP}(1.25-1.43 \mu \mathrm{g} / \mathrm{kg})$ formation than the EC limits stated above.

In general, the PAH levels of cooked beef reached their maximum values at high ohmic voltage level and high infrared temperature values in this study. However, the detection levels in all treatments were below the EC legal limits. For this reason, the ohmic cooking procedure followed by infrared cooking can be considered as safe in the context of PAH level.

\section{CONCLUSIONS}

In conclusion, lipid oxidation and PAH levels in cooked beef, caused by the electric current flow and high temperature, reached maximum values at high ohmic voltage levels and high infrared temperature values. For this reason, using 40 and 55 Volt values for ohmic cooking alone and $40 \mathrm{~V}-325^{\circ} \mathrm{F}, 40 \mathrm{~V}-375$ ${ }^{\circ} \mathrm{F}$ for ohmic-infrared cooking is thought to be better in order to obtain an acceptable TBARS threshold value ( $<1 \mathrm{mg} / \mathrm{kg}$ MDA). PAH detection levels for all treatments were below the EC legal limits. For this reason, both ohmic cooking alone and ohmic cooking followed by infrared cooking can be regarded as safe in the context of PAH level.

\section{ACKNOWLEDGMENTS}

The authors of this study are thankful to the Scientific Research Projects (BAP, MF14.14) Council in the University of Gaziantep.

\section{REFERENCES}

Autrup H, Daneshvar B, Dragsted LO, Gamborg M, Hansen AM, Loft S, Okkels H, Nielsen F, Nielsen PS, Raffn E, Wallin H, Knudsen, LE. 1999. Biomarkers for Exposure to Ambient Air Pollution-Comparison of CarcinogenDNA Adduct Levels with Other Exposure Markers and Markers for Oxidative Stress. Environ Health Perspect. 107, 233-238. https://doi.org/10.2307/3434514

Broncano JM, Petrón MJ, Parra V, Timón ML. 2009. Effect of different cooking methods on lipid oxidation and formation of free cholesterol oxidation products (COPs) in Latissimus dorsi muscle of Iberian pigs. Meat Sci. 83, 431-437. https:// doi.org/10.1016/j.meatsci.2009.06.021

Campo MM, Nute GR, Hughes SI, Enser M, Wood JD, Richardson RI. 2006. Flavour perception of oxidation in beef. Meat Sci 72, 303-311. https://doi.org/10.1016/j. meatsci.2005.07.015

Cheng JH. 2016. Lipid Oxidation in Meat. J. Nutr. Food Sci. 6, 1-3. https://doi.org/10.4172/2155-9600.1000494

Chung SY, Yettella RR, Kim JS, Kwon K, Kim M, Min DB. 2011. Effects of grilling and roasting on levels of polycyclic aromatic hydrocarbons in beef and pork. Food Chem. 129, 1420-1426. https://doi.org/10.1016/j.foodchem.2011.05.092

Duedahl-Olesen L, White S, Binderup ML. 2006. Polycyclic aromatic hydrocarbons (PAH) in danish smoked fish and meat products. Polycycl. Aromat. Compd. 26, 163-184. https://doi.org/10.1080/10406630600760527

EFSA, 2008. Scientific opinion of the panel on contaminants in the food chain on a request from the European Commission on Polycyclic Aromatic Hydrocarbons in Food. The EFSA Journal, 724. https://doi.org/10.2903/j.efsa.2008.724

European Comission (EC), 2011. Maximum levels for polycyclic aromatic hydrocarbons in foodstuffs. Commission Regulation (EC) No 835/2011, Official Journal of the European Union L215, 4-8.

Huang L, Sites J. 2012. Elimination of Listeria monocytogenes on cooked chicken breast meat surfaces by near-infrared surface pasteurization prior to final packaging. J Food Process Eng. 35, 1-5. https://doi.org/10.1111/j.1745-4530.2009.00551.x

Jira W. 2010. Polycyclic aromatic hydrocarbons in German smoked meat products. Eur. Food Res. Technol. 230, 447-455. https:// doi.org/10.1007/s00217-009-1187-9

Kazerouni N, Sinha R, Hsu C-H, Greenberg A, Rothman N. 2001. Analysis of 200 food items for benzo[a]pyrene and estimation of its intake in an epidemiologic study. Food Chem. Toxicol. 39, 423-436. https://doi.org/10.1016/ s0278-6915(00)00158-7

Kendirci P, İçier F, Kor G, Onogur TA. 2014. Influence of infrared final cooking on polycyclic aromatic hydrocarbon formation in ohmically pre-cooked beef meatballs. Meat Sci. 97, 123-129. https://doi.org/10.1016/j.meatsci.2014.01.020

Lyng JG, Zell M, Cronin DA, Morgan DJ. 2010. Ohmic cooking of whole beef muscle - Evaluation of the impact of a novel rapid ohmic cooking method on product quality. Meat Sci. 86, 258-263. https://doi.org/10.1016/j.meatsci.2010.04.007

Maillard MN, Soum MH, Boivin P, Berset C. 1996. Antioxidant activity of Barley and malt-relationship with phenolic content. Lesbensm. Wiss. Tech. 29, 238-44. https://doi.org/ 10.1006/fstl.1996.0035

Min S-G, Kim J-Y, Hong G-P, Park S-H, Spiess WEL. 2006. Effect of Ohmic Thawing on Physico-Chemical Properties of Frozen Hamburger Patties. Korean J. Food Sci. Ani. Resour. 26, 223-228.

Öz F, Yüzer MO. 2016. The effects of cooking on wire and stone barbecue at different cooking levels on the formation of heterocyclic aromatic amines and polycyclic aromatic hydrocarbons in beef steak. Food Chem. 203, 59-66. https://doi.org/10.1016/j.foodchem.2016.02.041

Panalaks T. 1976. Determination and identification of polycyclic aromatic hydrocarbons in smoked and charcoal-broiled food products by high pressure liquid chromatography. $J$. Environ. Sci. Health. 11, 299-315. https://doi.org/10.1080/ 03601237609372045

Park K-C, Pyo HS, Kim WS, Yoon KS. 2017. Effects of cooking methods and tea marinades on the formation of benzo[a] pyrene in grilled pork belly (Samgyeopsal). Meat Sci. 129, 1-8. https://doi.org/10.1016/j.meatsci.2017.02.012

Peiretti PG, Medana C, Visentin S, Dal Bello F, Meineri G. 2012. Effect of cooking method on carnosine and its homologues, pentosidine and thiobarbituric acid-reactive substance contents in beef and turkey meat. Food Chem. 132, 80-85. https://doi.org/10.1016/j.foodchem.2011.10.035

Piette G, Buteau ML, Halleux, D de, Chiu L, Raymond Y, Ramaswamy HS, Dostie M. 2004. Ohmic cooking of processed meats and its effects on product quality. J. Food Sci. 69, 71-78. https://doi.org/10.1111/j.1365-2621.2004. tb15512.x

Ramaswamy HS, Marcotte M, Sastry S, Abdelrahim K. 2014. Why Ohmic Heating? Advantages, Applications, Technology, and Limitations, Sastry, S. Electro-technologies for Food Processing Series - Ohmic Heating in Food Processing, 7-8.

Reinik M, Tamme T, Roasto M, Juhkam K, Tenno T, Kiis A. 2007. Polycyclic aromatic hydrocarbons (PAHs) in meat products and estimated PAH intake by children and the general population in Estonia. Food Addit. Contam. 24, 429-437. https://doi.org/10.1080/02652030601182862

Soladoye OP, Shanda P, Dugan MER, Gariépy C, Aalhus JL, Estévez M, Juárez M. 2017. Influence of cooking methods and storage time on lipid and protein oxidation and heterocyclic aromatic amines production in bacon. Food Res. Int. 99, 660-669. https://doi.org/10.1016/j.foodres.2017.06.029 
10 • A. Uzun Özcan, M. Maskan, M. Bedir and H. Bozkurt

Vasanthi C, Venkataramanujam V, Dushyanthan K. 2007. Effect of cooking temperature and time on the physico-chemical, histological and sensory properties of female carabeef (buffalo)meat. Meat Sci. 76, 274-280. https://doi.org/10.1016/j. meatsci.2006.11.018

Wu WH, Rule DC, Busboom JR, Field RA, Ray B. 1991. Starter culture and time/temperature of storage influences on quality of fermented mutton sausage. J. Food Sci. 56, 916919. https://doi.org/10.1111/j.1365-2621.1991.tb14605.x
Yildiz-Turp G, Sengun IY, Kendirci P, İçier F. 2013. Effect of ohmic treatment on quality characteristic of meat: A review. Meat Sci. 93, 441-448. https://doi.org/10.1016/j.meatsci. 2012.10.013

Zell M, Lyng, JG, Cronin, DA, Morgan, DJ. 2010a. Ohmic cooking of whole beef muscle - Evaluation of the impact of a novel rapid ohmic cooking method on product quality. Meat Sci. 86, 258-263. https://doi.org/10.1016/j.meatsci. 2010.04.007 